\title{
The Determination of Moisture in Parchment Coffee and Green Coffee Beans with a Dielectric-type Moisture-Meter
}

\author{
D. S. Boyce ${ }^{1}$
}

\section{INTRODUCTION}

It is becoming increasingly important for those concerned with the production, processing, and handling of seedlike products to have an accurate and rapid method of determining their moisture content. Zeleny $(19)^{2}$ stated that the moisture content is one of the most important factors affecting the quality of grain. Since the moisture content bears an inverse relationship to the amount of dry matter per unit weight of material, it is by itself a matter of direct economic importance. Of even greater significance, however, is the effect of moisture content on the keeping quality of grain. Dry, sound grain, if properly stored, may be kept for years with little deterioration in quality, but wet grain may spoil completely within a few days. It is not possible, however, to set precise moisture limits for the safe storage of grain or to predict accurately how rapidly it will deteriorate at any given moisture content, because various factors other than moisture have a marked effect on storage behavior. Nevertheless, under practical storage conditions, moisture content is usually the principal factor governing the keeping quality of grain. Hall (11) stated that moisturecontent determinations to within 1 percent are usually sufficient to establish whether grain will keep in storage.

In addition to the factors mentioned above, methods of moisture determination should be associated with all drying operations, especially when artificial means are employed, so that its end point may be determined and that the drying is not uneconomically prolonged beyond the point where further reduction in moisture content is advantageous. It has also been reported (18) that both the method of drying and the moisture content of the coffee seed (parchment coffee) are important to their retention of viability in storage.

It will be noted that these introductory remarks concerning seedlike

${ }^{1}$ Assistant Professor, Department of Agricultural Engineering, College of Agriculture and Mechanic Arts, Mayagüez, P. R. The author wishes to acknowledge the cooperation of Assoc. Prof. of Agronomy R. Pietri-Oms in providing laboratory facilities and equipment; and to D. Haddock, formerly Assistant Agricultural Engineering II, Department of Agricultural Engineering, who carried out the laboratory work involved in collecting the experimental data.

2 Italic numbers in parentheses refer to Literature Cited, pp. 102-3. 
products in most instances have been made originally with reference to the grains of commerce of the Temperate regions rather than to coffee products. This is because most of the investigations concerning moisture-content relationships in such products have been carried out in Temperate regions and comparatively little attention has been given to moisture determinations of coffee products.

As an initial step in a program to investigate coffee-processing problems, the Agricultural Engineering Department of this Station surveyed the various methods of moisture determination applicable to seedlike products and especially to coffee. Apparently no previous consideration had been given in Puerto Rico to the use of rational methods for moisture determinations of coffee, and all techniques for assessing moisture content seemed to be based on visual examinations by those concerned with the trade. Llewelyn (14) reported that planters in Kenya judged the moisture content of coffee in the 8- to 12-percent range to within about \pm 1 percent in their own areas. In the range of 15- to 40-percent judgment of coffee moisture content was reported to be very unreliable.

As a result of a survey (14) carried out on a worldwide basis under the auspices of the Coffee Board of Kenya it was concluded that, of all the types of moisture-meters which might be applicable to coffee, by far the most suitable was the Kappa moisture-meter, marketed by Messis. Kappa Moisture-Meters, Ltd. After considering this report the Agricultural Engineering Department placed an order for a similar meter. The instrument Serial No. $\mathbf{7 7 5 5}$ arrived early in 1958, and was calibrated for both parchment and green coffee during the latter part of the same year.

The Kappa meter uses an indirect method of determining moisture based on measuring the dielectric properties of the material. These, in turn, are related to the moisture content. For a general discussion of this and other direct and indirect secondary methods of moisture determination the reader is referred to Zeleny (19) and to Anderson and Alcock (1). Llewelyn (14) also discussed the advantages and limitations of the Kappa (or dielectrictype) meter for determining moisture in parchment coffee. The details of the Kappa moisture-meter are described in literature obtainable from the manufacturer $(8)$. The meter itself is shown with the various accessories in figure 1.

\section{REVIEW OF LITERATURE}

Aside from the work carried out by the Coffee Board of Kenya, already referred to, only two other reports of specific investigations of moisture determination in coffee have been noted. Barton and Goenaga (2) investigated the suitability of a resistance-type meter, the Universal Electrical Moisture Tester, for determining the moisture content of "coco" within 
the range of 10- to 23-percent moisture content, wet basis, hereafter m.c.w.b. ${ }^{3}$ (8.25 to 18.70 percent m.c.w.b.). "Coco" is described by these authors as a heterogeneous mixture of whole fruits, broken fruits, clean seed, and fruit coats, with whole fruits comprising most of the mixture. As this material was reported to have originated in Brazil it has obviously been prepared by the "dry process" which results in Brazilian or "hard coffee." Coffee produced in Puerto Rico and other areas using the "wet process" is referred to as "mild coffee." In processing coffee by the "wet process" parchment coffee is first produced. A parchment coffee consists of one of the socalled coffee "beans" of commerce hereafter referred to as green coffee. Each "bean" is enclosed in a thin membrane called "silver skin" and then in a

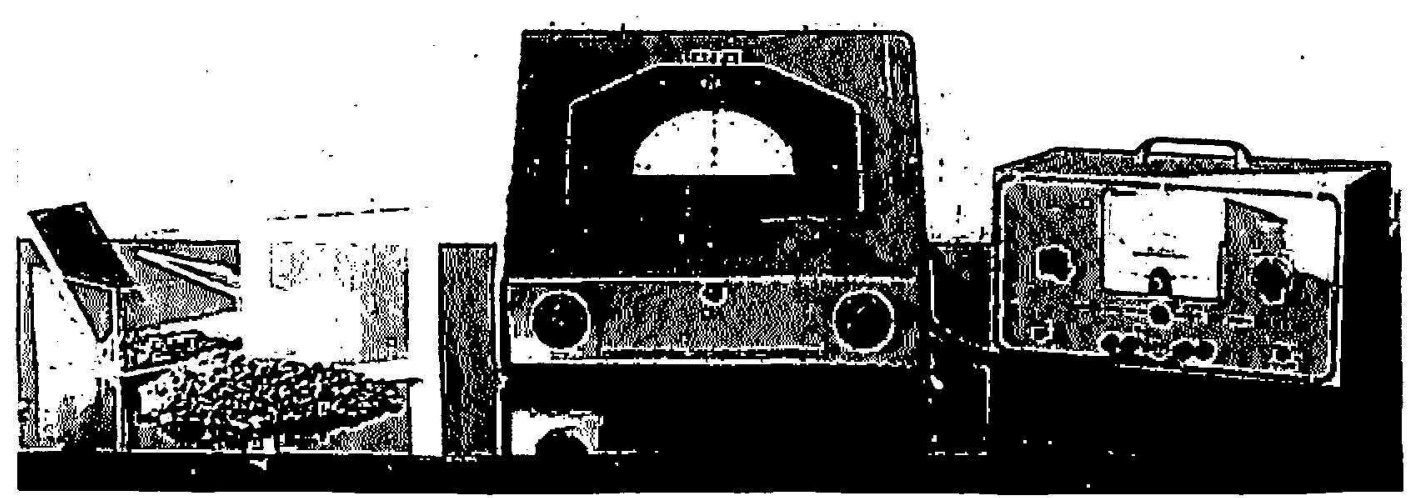

Fig. 1.-The Kinpa moisture-meter; a special filling tray on the extreme left is adjacent to the sample container; the instrument on the right is a voltage-control regulator.

parchmentlike shell. The two coffee materials of this study were clean parchment coffee and green coffee, consequently no exact comparison can be made with the work of Barton and Goenaga.

Schwartzman (16) stated that very little work had been done on the moisture determination of green coffee. He reported on a few trials com-

3 There are 2 methods of designating the moisture content: 1, Wet basis, and, 2, dry basis. The moisture content on a wet basis is obt ained by dividing the weight of water present in the material by the total weight of the material. The percentage moisture on a dry basis is determined by dividing the weight of water by the weight of dry matter. Thus:

Percent moisture content dry hasis $=\left(H_{m} / W^{\prime} d\right) \times 100$ (percentage m.c.d.b.) Percent moisture content wet hasis $=[W m /(H m+W d)] \times 100$ (percentage m.c. w.l.).

where $\mathrm{Wm}=$ weight of moisture in sample

IV $d=$ weight of dry matter in sample. 
paring air-oven methods of moisture determination with a toluene-distillation method. Finally, Ives (1S), and Goto and Fukunaga (9) mentioned the use of electrical meters for determining moisture in parchment coffee, but they gave no details of the equipment used or of its suitability.

In contrast with the rather meager investigations into the moisture determination of coffee products a great deal of attention has been devoted to investigating various methods and moisture-meters for determining moisture in grain products. An excellent survey of the extensive work in this field is given by Anderson and Alcock (1). In comparing work in moisture determination in the cereal field with work on parchment coffee it should be noted that, with cereals, moisture is generally determined over the range 10 to 20 percent m.c.w.b. However, with coffee parchment it must in some instances be made over a range of perhaps 10 to 50 percent m.c.w.b. whereas for green coffee a range of from 8 to 20 percent m.c.w.b. is probably adequate for most purposes.

\section{EXPERIMENTAL PROCEDURE}

When using secondary or indirect methods of moisture determination it is not the actual moisture content of the material which is measured, but some other property instead, such as the electrical resistance or conductivity or, in the case of the Kappa and similar meters, the dielectric constant or the capacitance. Consequently, these meters which measure secondary factors dependent on moisture content must be calibrated by some primary method of moisture determination so that the secondary factor may be expressed in terms of moisture content.

Some of the more frequently used of these primary methods are described, as previously mentioned, by Anderson and Alcock (1). Two factors determined the choice of the primary method selected. In the first place it was desirable to use a method which others had already found satisfactory for work with coffee. Secondly, the method should be such that the fairly large number of primary determinations necessary for the calibration of the meter over the required ranges for parchment coffee and green beans could be carried out conveniently. The method which was considered most satisfactory for this purpose was a distillation process known as the "Dean and Stark Method" (7). It involves distilling the material under test with a liquid, xylene, having a boiling point higher than that of water and which is also lighter than, and immiscible with water. The distillation is carried out with a special distillation receiver which enables water to be collected in a graduated cylinder, while the excess of the distillation liquid is allowed to run back into the distillation flask. The equipment for this type of moisture determination is similar to that sometimes known as the BedwellSterling apparatus ( 3 ). The contents of the distillation receiver could be read directly to $0.2 \mathrm{cc}$. and estimated to one-tenth. 
All the coffee used was Coffea arabica which originated from the College Farm, Mayagüez. It was obtained either as washed and fermented wet parchment or as semidried parchment. The parchment coffee was then dried down to the desired moisture content. In the range down to about 15 percent m.c.w.b. drying was carried out by exposing a single layer to the sun; below this level it was occasionally necessary to dry the parchment in a laboratory oven at a temperature of about $125^{\circ} \mathrm{F}$. In no case was it necessary to wet the parchment artificially, though at the lower end of the moisture-content range it was found necessary in some instances to adjust the moisture content upwards by exposing the parchment in a single layer to the ambient air.

The green coffee was obtained from the parchment of the appropriate moisture content using a small hand-huller. Its moisture content was reduced when required by either sun- or oven-drying in single layers, though again, in some instances, it was found necessary in the extreme lower range to raise the moisture content of a particular sample by exposing it to the ambient air.

When a sample of either parchment or green coffee had reached what was estimated to be a desired moisture content it was sealed in double plastic bags and stored at least overnight, adjacent to the moisture-meter. This was to allow the moisture content of the sample to become uniform and for its temperature to approach that of the room.

It became obvious as soon as initial trials were undertaken that, with material the moisture content of which must be measured over a considerable range, and especially with coffee parchment, that it would be difficult to comply with the manufacturer's (15) instructions that samples of constant weight be used. It was found that because of very considerable changes in bulk density with moisture content, the instructions specifying that a sample of constant weight should be compressed to fill the sample container to a given volume could not be complied with. This is because, as it is shown later, increasing bulk densities are associated with increasing moisture contents for parchment coffee while, for green coffee, increasing bulk density is associated with decreasing moisture content. The sample container used had a useful capacity of $1,030 \mathrm{cc}$. and was designated as the No. 2 container by the manufacturer.

As a result of these observations it was decided that the most fruitful approach would be to compact the contents of the sample containers as uniformly as possible, first by shaking down the contents and, finally, by compressing them to the line indicating maximum fill with a piece of wood, such as is shown on the extreme left of figure 1. Figure 2A and B shows the sample container loosely filled with parchment coffee and also the same parchment compressed to the maximum-fill line. Thercfore, in each case after the meter reading had been made, the weight of the material in the 


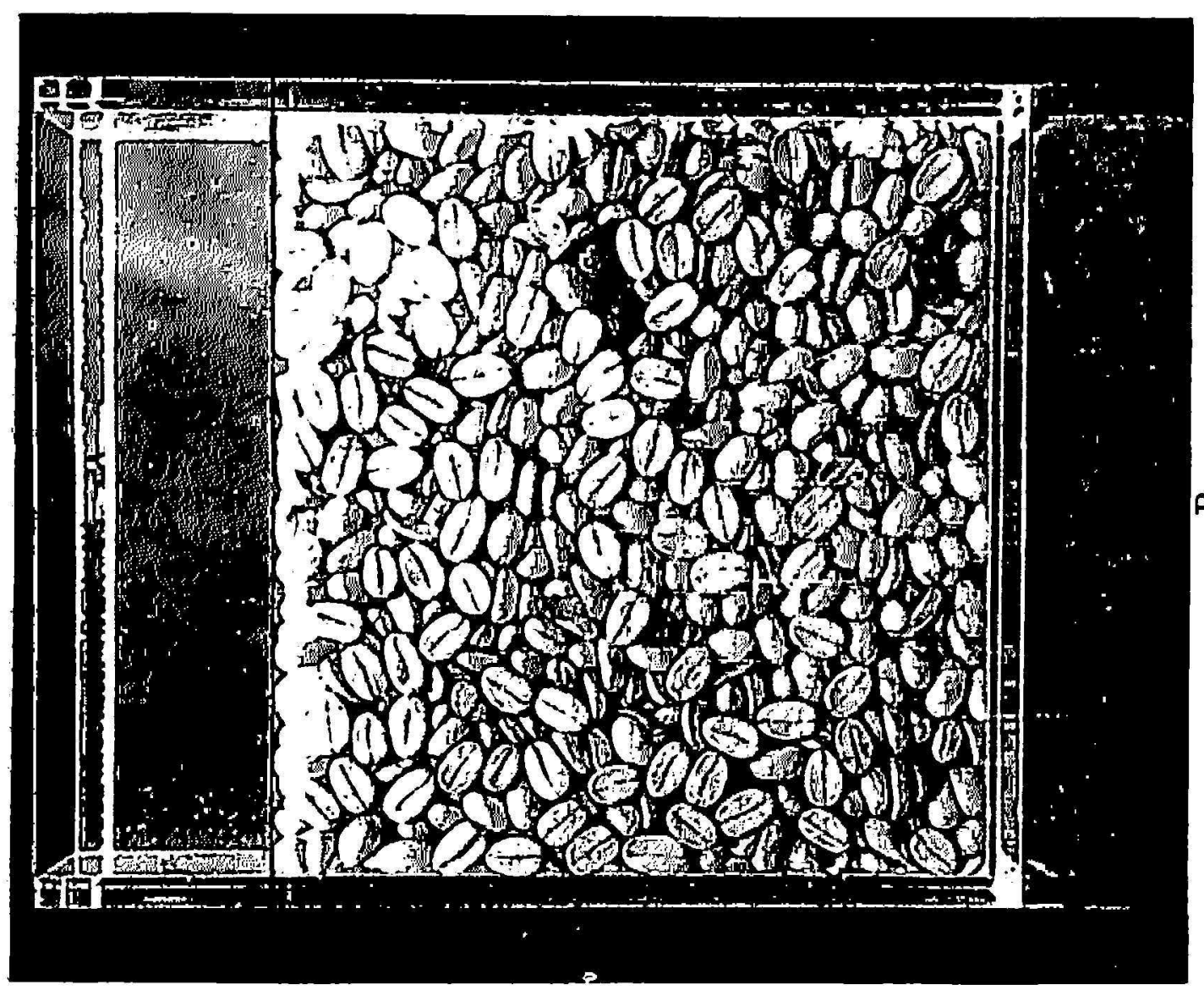

严

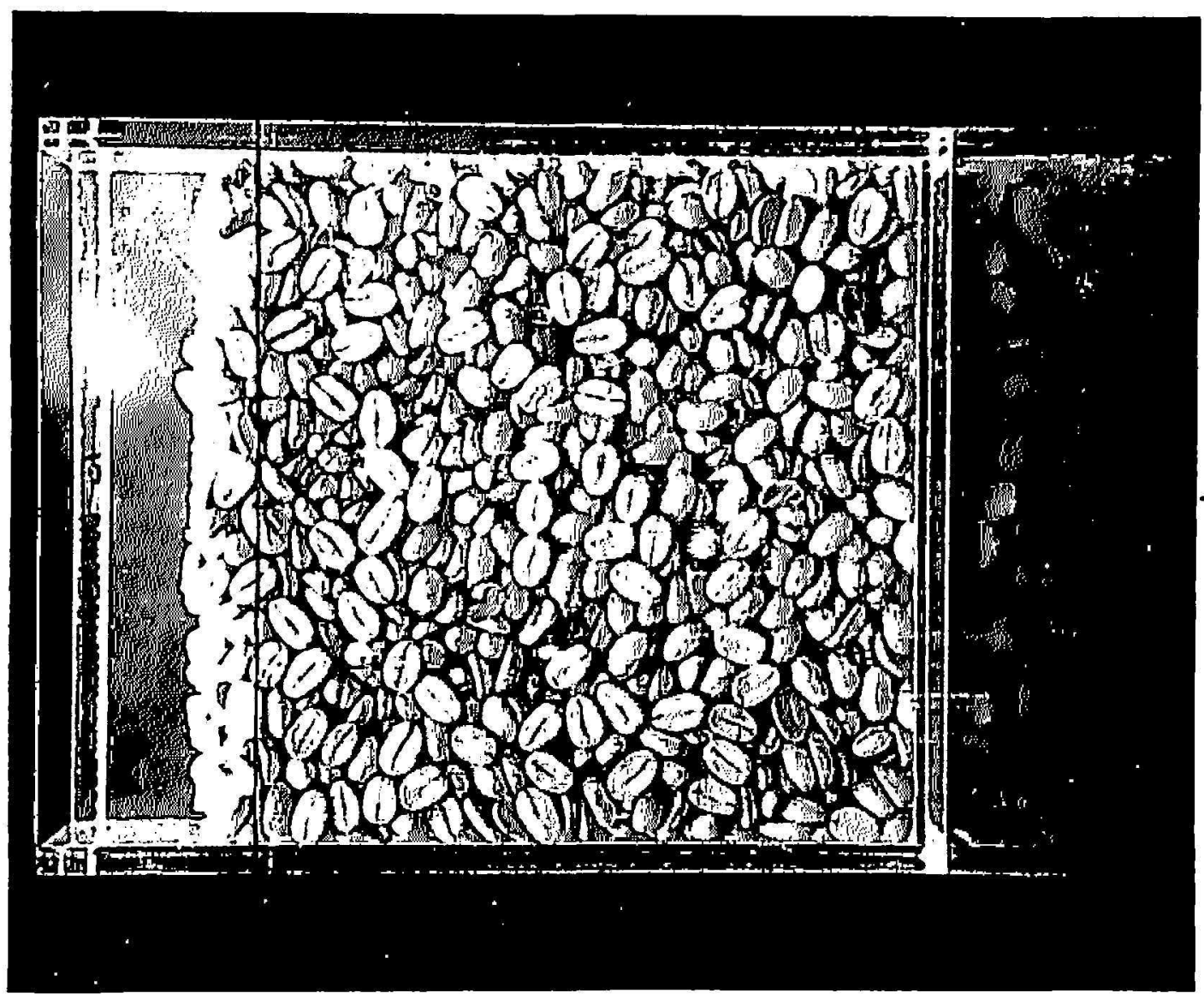

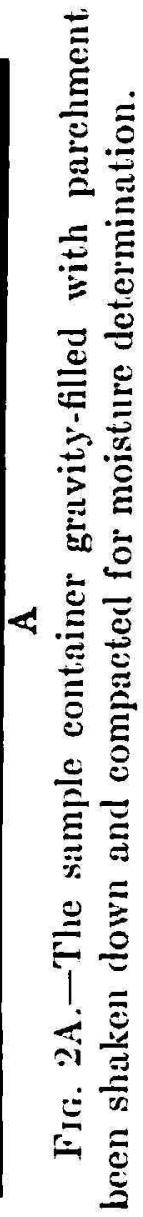


sample container was determined in grams. The importance of recording of the weight of the sample is discussed later.

An important check was found against overcompressing the material in the sample container. If its contents were overcompressed the plastic container was slightly distorted. This was sufficient to prevent it from being fitted into the meter. If there was any indication of interference between the meter and the filled sample container, it was emptied and refilled.

A further factor likely to influence the meter readings is that of temperature. Ideally, it would have been desirable to carry out all determinations at constant temperature, but this was impossible. The ambient temperature about the meter during trials was observed to vary from $76^{\circ}$ to $83^{\circ} \mathrm{F}$; h however, as explained later, all the meter readings were corrected to an arbitrarily selected temperature of $80^{\circ} \mathrm{F}$.

In order to determine the temperature-correction factor, all samples were first tested in the Kappa meter at prevailing ambient temperatures. Then the individual samples were sealed in double plastic bags and placed together with the meter in an air-conditioned room where temperatures. were on an average $8^{\circ} \mathrm{F}$. less. After remaining at least 12 hours so as to allow for a uniform temperature to be reached, Kappa meter readings were again obtained for each sample. In each instance the ambient temperature was recorded.

The only other factor besides the weight of the sample and the temperature which might have affected the meter reading was ambient humidity; however, it was felt that it was not feasible to investigate this factor and its influence was also considered likely to be negligible. Cook et al. (4) working with resistance-type meters considered that a 10-percent change in the relative humidity of the test room had the same effect as, or less effect than a $1^{\circ} \mathrm{F}$. change in temperature, and thought that no corrections were necessary if the relative humidity varied less than \pm 10 percent. It was estimated that the variations of the ambient conditions under which the meter readings were taken were probably largely within this range.

A total of 16 samples of parchment coffee, each divided into 4 subsamples, varying from a recorded moisture content of 48.8 down to 5.0 percent m.c.w.b. were examined. Similarly, 11 samples of green coffee, each divided into 4 subsamples, and ranging from 4 up to 30.6 percent m.c.w.b. were used. All the meter readings and moisture determinations were carried out by a single person. The primary moisture determinations by the Dean and Stark method were made only after the Kappa meter readings had been made at two different temperatures using a proportion of the material from each subsample. 


\section{EXPERIMENTAL RESULTS}

All the results were subjected insofar as possible to statistical analysis. This consisted basically of calculating linear regression equations for the appropriate unknowns. It was assumed after considering the results that all relationships within the range investigated could be considered as linear.

The following notation has been adopted:

$$
\begin{aligned}
x_{1}= & \text { Kappa meter reading at temperature } T_{1} . \\
x_{2}= & \text { Kappa meter reading at temperature } T_{2} . \\
x_{1 c}= & \text { Kappa meter reading corrected to } 80^{\circ} \mathrm{F} . \\
x_{3}= & \text { Weight of material; (gm.) in sample container. } \\
y_{1}= & \text { estimated percent m.c.w.b. determined from } x_{1} . \\
y_{1 c}= & \text { estimated percent m.c.w.b. determined from } x_{1 c} . \\
y_{1 c d}= & \text { estimated percent m.c.w.b. determined from } x_{1 c} \text { and } x_{3} \text { or } x_{1}, \\
& x_{3} \text { and } T_{1} . \\
y_{1 d}= & \text { estimated percent m.c.w.b. determined from } x_{3} . \\
T_{1}= & \text { ambient temperature }{ }^{\circ} \mathrm{F} . \text { at which } x_{1} \text { was made. } \\
T_{2}= & \text { ambient temperature }
\end{aligned}
$$

Let $W=T_{2}-T_{1}$ and $Z=x_{2}-x_{1}$

$S=$ the standard deviation from the regression, or standard error of estimate, as indicated.

$S_{y}=$ the standard error of $y$ as indicated.

(where $y$ reads regression $y$ or estimated y or predicted $y(17)$ ).

$r_{y x}=$ correlation coefficient as indicated by the appropriate subscript.

$N=$ number of pairs of observations.

\section{RELATIONSHIPS FOR PARCHMENT COFFEE}

1. $y_{1}=0.0092_{x 1}-19.53$

with $S=1.73$ percent, $S_{\nu}=0.42$ percent at min. $x_{1}$ value and

0.47 percent, at $\max . x_{1}$ value observed, and $N=64$.

2. $y_{1 c}=0.0092_{x 1 c}-19.53$

with $S=1.63$ percent, $S_{u}=0.40$ percent at min. $x_{1 c}$ value and

0.41 percent at $\max . x_{1 c}$ value observed, and $N=64$.

3.

$$
\begin{aligned}
\text { A, } \quad y_{1 c d}= & 0.0057 x_{1 c}+0.07 x_{3}-37.51 \\
& \text { or } \\
\text { B, } \quad y_{1 c d}= & 0.0057 x_{1}+0.071 x_{3}-0.045 T_{1}-33.83 \\
& \text { with } S=0.58 \text { percent, } S y=0.38 \text { at min. values } \\
& \text { of } x_{1 c} \text { and } x_{3}, \text { and } 0.68 \text { percent at max. values } \\
& \text { of } x_{1 c} \text { and } x_{3} \text { observed, and } N=64 .
\end{aligned}
$$


4.

$$
\begin{aligned}
\mathrm{A}, \quad Z= & 7.81 \mathrm{~W}+19.37 \\
& \text { with } r_{z w}=0.62^{4}, S_{z w}=35.68 \text { and } N=60 \\
& \text { or } \\
\mathrm{B}, x_{2}-x_{1}= & 7.81\left(T_{2}-T_{1}\right)+19.37 \\
& \text { or } \\
& \text { if } x_{2}=x_{1 c} \text { and } T_{2}=80^{\circ} \mathrm{F} . \\
\mathrm{C}, \quad x_{1 c}= & x_{1}-7.81 T_{1}+644.17
\end{aligned}
$$

5. $y_{1 d}=0.21 x_{3}-76.37$

with $r_{y x 3}=0.97^{4}, S=2.22$ percent, $S y=0.53$ percent at min. values of $x_{3}$ and 0.89 percent and at max. value of $x_{3}$ observed, and $N=64$.

\section{RELATIONSHIPS FOR GREEN COFFEE}

6. $y_{1}=0.0051 x_{1}-13.44$ with $S=1.24$ percent, $S y=0.30$ percent at $\min . x_{1}$ value and 0.38 percent at $\max . x_{1}$ value observed, and $N=44$.

7. $y_{1 c}=0.0052 x_{1 c}-14.00$ with $S=1.13$ percent, $S y=0.28$ percent at $\min . x_{1 c}$ value and 0.38 percent at $\max . x_{1 c}$ value observed, and $N=44$.

8.

$$
\begin{aligned}
& \mathrm{A}, \quad y_{1 c d}= 0.0049 x_{1 c}-0.044 x_{3}+17.77 \\
& \text { or } \\
& \mathrm{B}, \quad y_{1 c d}= 0.0049 x_{1 c}-0.044 x_{3}-0.10 T_{1}+25.54 \\
& \text { with } S=0.769 \text { percent, } S y=0.24 \text { percent at } \\
& \text { min. } x_{1 c} \text { and max. } x_{3} \text { and } 0.25 \text { percent at } \\
& \text { max. } x_{1 c} \text { and min. } x_{3} \text { values, and } N=64 \\
& \mathrm{~A}, \quad Z= 20.14 W-25.89 \\
& \text { with } r_{z w}=0.78^{4}, S w=63.47 \text { and } W=44 \\
& \text { or } \\
& \text { B, } x_{2}-x_{1}= 20.14\left(T_{2}-T_{1}\right)-25.89 \\
& \text { or } \\
& \text { if } x_{2}=x_{o} \text { and } T_{2}=80^{\circ} \mathrm{F} . \\
& x_{c}=x_{1}-20.14 T_{1}+1,585.31
\end{aligned}
$$

9.

10. $y_{1 d}=139.67-0.18 x_{3}$

$$
\text { with } r_{u x 3}=-0.47^{4}, S=6.87 \text { percent and } N=44 \text {. }
$$

In addition to equations 1 to 10 showing the results of these investigations figure 3 shows a scatter diagram of the values of $x_{1 r}$ and the corresponding values of $y_{1 c}$, determined by the Dean and Stark method with regression 2 , shown as a solid line. Figure 4 shows the corresponding scatter diagram for the values obtained for green coffee. Regression 7 is shown on the diagram as a solid line.

- Significant at 1-percent level. 


\section{DISCUSSION}

All the relationships established were assumed after examination to be linear over the ranges investigated. That is from 5 to 48 percent m.c.w.b.

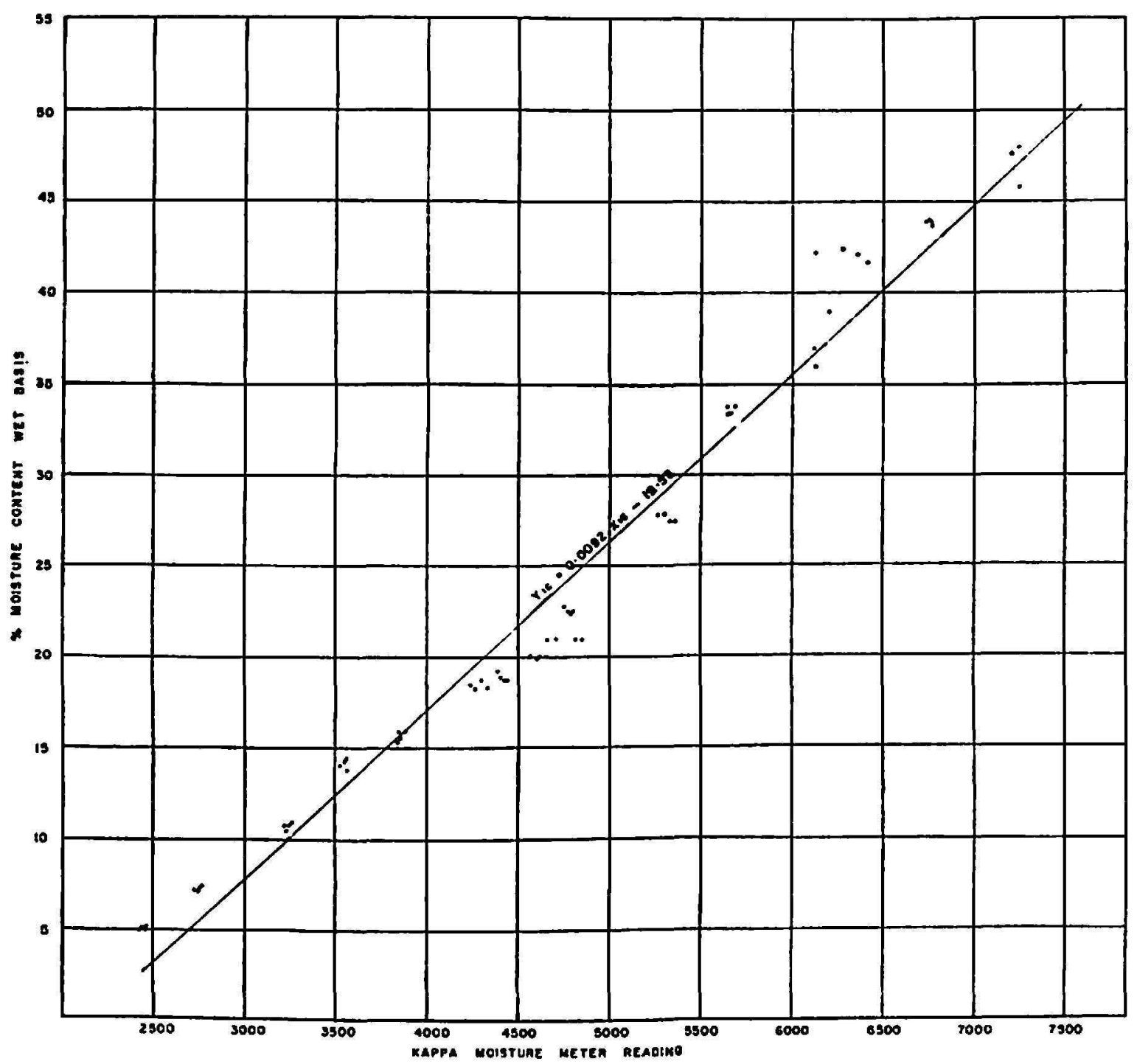

FIG. 3.-A scatter diagram showing the relationship between the percentage moisture content, wet basis (Dean and Stark Method), and the Kappa moisture-meter readings corrected to $80^{\circ} \mathrm{F}$. for parchment coffee. The corrected regression line is shown as a solid line.

for parchment coffee, corresponding to meter-readings of 2,350 to 7,280 at temperatures varying from $84^{\circ}$ to $67^{\circ} \mathrm{F}$. Similar values for green coffee provided an observed moisture content ranging from 4 to 30.8 percent m.c.w.b., with corresponding meter readings of 3,560 to 8,264 over the same temperature range. In all instances the manufacturer's No. 2 sample container was used. It is thought that the range of moisture content studied include the extremes likely to ever be encountered in practice and, 
therefore, the range of the meter may be considered quite sufficient for work with coffee products. The meter dial has 10,000 divisions.

It can be shown for parchment coffee from equation 2 that a change of

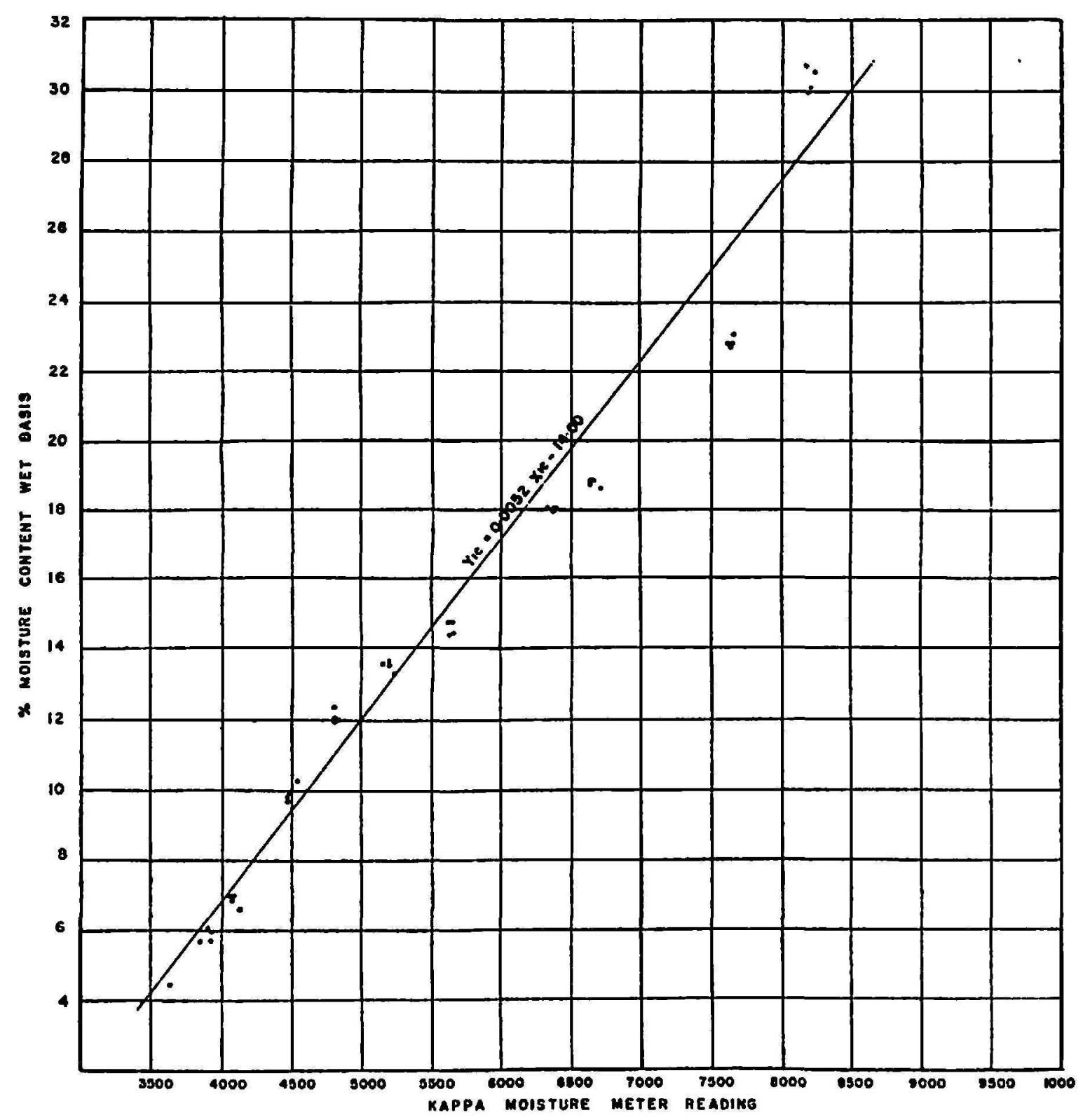

Fig. 4.-A scatter diagram showing the relationship between the percentage moisture content, wet basis (1)an and Stark Method), and the Kappa moisture-meter readings corrected to $80^{\circ} \mathrm{F}$. for green coffee beans. The corrected regression line is shown as a solid line.

1 percent m.c.w.b. is equivalent to approximately 109 meter divisions and from equation 7 the corresponding value is $\mathbf{1 9 2}$ meter divisions for green coffee; therefore, the value of the moisture content can be directly determined from the meter reading within at least two decimal points. Furthermore, as initial trials indicated that with a little experience an operator 
could more or less duplicate readings using the same sample, it is considered that the sensitivity of the Kappa moisture-meter is sufficient for most purposes.

It is apparent from comparing the standard deviations of the regression $S$ of equations 1,2 , and 3 , and 6,7 , and 8 , that it is reduced progressively as the effects of temperature and the weight of the material in the sample container are considered. However, without replications which would have greatly increased the number of moisture determinations required, it was not possible to determine any statistically significant differences between the various values of $S$ with the data available. However, it is probable that, had a number of independent estimates of $S$ been available for both parchment coffee and green coffee, statistical evidence of differences would have been shown.

The values of $S$, that is 0.77 for green coffee and 0.58 for parchment coffee, associated with equations 3 and 8 compare very favorably with similar values obtained by other workers using different meters and materials when the much greater range over which the determinations were made are considered. Representative values of $S$ obtained with Canadian hard red spring wheat over the range of 11 to 17 percent of moisture, determinations being made by the oven method for six dielectric meters, varied from 0.35 to 0.50 percent (12). It should again be noted that the statistical significance between standard errors of estimate $S$ cannot be computed from a single study and, therefore, it is not possible to say what would represent a significant difference between two different standard errors of estimate.

As the value of $N$, the number of observations used to determine each regression equation, is shown, as well as the value of the standard error $S y$ for the extreme values encountered, it is possible to make fiducial statements about the corresponding values of any $y$ at any desired probability level by referring to an appropriate " $\mathrm{t}$ " table.

Equations $4 \mathrm{~A}, 4 \mathrm{~B}$ and $4 \mathrm{C}$ and $9 \mathrm{~A}, 9 \mathrm{~B}$, and $9 \mathrm{C}$ show the relationship between changes in Kappa moisture-meter readings due to change in the ambient temperature for coffee parchment and green coffee beans.

The corresponding correlation coefficients of $Z$ and $W$ are shown in each instance and are highly significant. Equations $4 \mathrm{C}$ and $9 \mathrm{C}$ are the expressions used to correct the Kappa moisture-meter readings to $80^{\circ} \mathrm{F}$. and used to establish regressions $2,3 \mathrm{~A}, 7$ and $8 \mathrm{~A}$. It can be shown from regression $4 \mathrm{~A}$ that a temperature change of $5^{\circ} \mathrm{F}$. would cause the meter reading to change by 58.42 units which represent 0.54 percent m.c.w.b. for coffee parchment. The corresponding figure for green coffee is a change of meter reading of 74.81 units, corresponding to a moisture content of 0.39 percent m.c.w.b. Therefore, if considerable variations in ambient tempera- 
ture occur when meter readings are being made, erroneous and misleading results may be obtained unless temperature effects are taken into consideration.

Equations 5 and 10, respectively, show the relationship between the weight of material in the sample container and the moisture content of parchment and green coffee. The coefficient of correlation is significant in each case at the 1-percent level. It is positive in the first instance and negative in the second. It is to be assumed that, as the moisture content of green coffee is reduced, there is a proportionally greater shrinkage. This matter is only incidental to this study and should be further investigated.

Equation 5, showing the relationship between the weight of a unit volume, the useful volume of the sample container, and the moisture content of parchment coffee, is of considerable interest. It is surprising that there is such a close relationship between the unit volume weight of parchment coffee and its moisture content. Calculating the fiducial limits associated with values of $y_{1 d}$ for the extreme values observed of the weight of material in the sample container gave the following results: An observed value of $x_{3}=403 \mathrm{gm}$. gave a calculated value of $y_{1 d}=8.26$ percent m.c.w.b. This corresponding value determined by the Dean and Stark method was 5.2 percent m.c.w.b. Corresponding values for $x_{3}=555 \mathrm{gm}$., and the maximum value observed resulted in a calculated value of $y_{1 d}=40.18$ m.c.w.b., corresponding to a determined moisture content of 37.4 percent m.c.w.b. The fiducial limits associated with the predicted values of moisture content at the 5- and 1-percent confident limits respectively are:

Minimum value $(8.126) \pm 1.07$ percent and \pm 1.43 percent

Maximum value (40.18 percent) \pm 1.80 percent and \pm 2.40 percent

It is apparent that the values determined at the extremes of the range considered, and especially at the lower end, tend to be high. It is possible, however, that this relationship might be found sufficiently close if further investigations were undertaken to form the basis of a method of moisture determination sufficiently accurate to be used to control the operation of small on-the-farm artificial driers for parchment coffee.

A consideration of the number of variables involved in accurately determining the moisture content of either coffee parchment or green coffee with a Kappa moisture-meter shows that it would be quite laborious to make the calculations indicated by equations 3 and 8 each time it was necessary to determine the moisture content of a sample. In fact, if the moisture is to be determined from one variable only, that is the meter reading, there would still be difficulties in quickly converting this reading to moisture content from the regression equation. This, of course, can be 
overcome, if only a single variable is being considered, by using some type of conversion scale or chart.

If, however, the moisture content is to be determined from the Kappa meter readings, the weight of the sample and the ambient temperature, probably the most convenient way of quickly determining the moisture
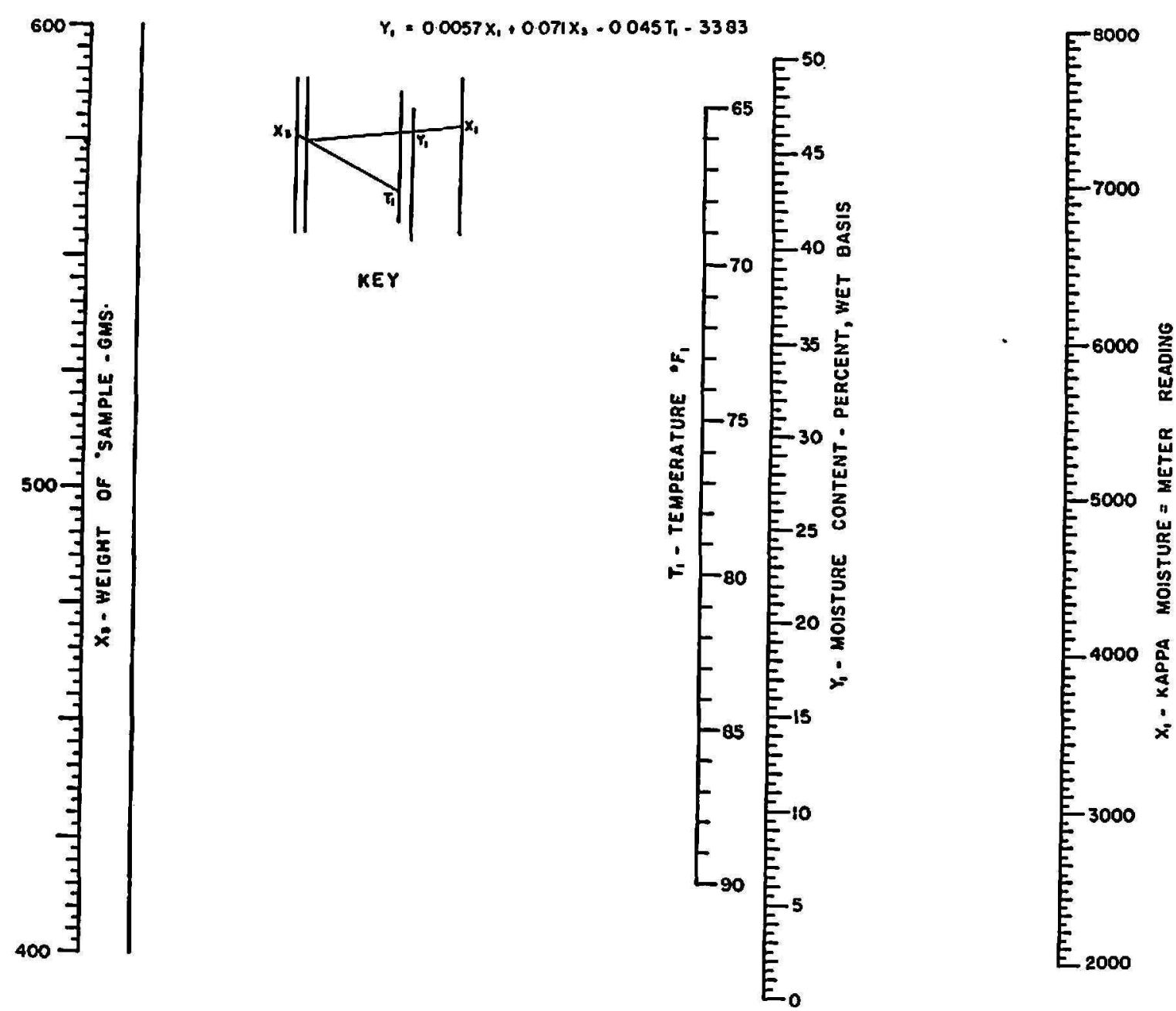

Fig. 5.-A 4-variable addition-type alignment chart for determining the moisture content of parchment coffee if the Kappa moisture-meter reading, the weight of the material in the sample container (grams), and the ambient temperature ( ${ }^{\circ} \mathrm{F}$.) are known.

content is by the use of an alignment chart or nomogram (6). The fourvariable addition-type alignment chart is one of the simpler types to construct $(5)$ and is suitable for obtaining solutions to equations $3 \mathrm{~B}$ and $8 \mathrm{~B}$. Figure 5 shows the alignment chart for rapidly providing solutions to equation (3B).

It is unlikely that the linear regressions obtained for Kappa moisturemeter, Serial No. 7755 would be applicable to other meters of the same 
kind. However, if additional moisture-meters for coffee parchment and green coffee should be required, they could be calibrated against meter No. 7755 rather than by the more tedious primary methods. This instrument is now installed in the laboratories of the Agricultural Engineering Department of the University of Puerto Rico at Mayagüez, and it can be made available for the purpose of standardizing further instruments when necessary. Its calibration will be checked periodically against the Dean and Stark Method.

\section{SUMMARY}

1. It is necessary for all those concerned with the production, processing, and handling of seedlike products such as coffee parchment and green coffee to have available a method for the rapid and simple determination of moisture content.

2. A review of the literature indicates that much work has been done on the moisture determination of the seed of commerce of the Temperate regions, but little information exists concerned with the moisture determination of coffee.

3. As an initial step in setting up a program to investigate methods of coffee-processing it was necessary to establish a quick, simple, and accurate method of moisture determination. Investigations by others indicated that the Kappa moisture-meter, manufactured by Messrs. Kappa Moisture Meter Ltd., U. K., was probably the most suitable instrument available for this purpose.

4. It was decided to use a distillation method as the primary means of establishing the relationship between the moisture content of the material and the meter reading. It was found that it was not only necessary to determine the meter reading but also the weight of the sample and the ambient temperature if reliable results were to be obtained.

5. The Kappa moisture-meter was calibrated both for coffee parchment and green coffee over the widest possible range of moisture contents likely ever to be encountered.

6. All the results were statistically evaluated. It was found that, if the weight of the sample and the ambient temperature were taken into consideration, the standard deviation from the regression or the standard error of estimate for both parchment and green coffee were very comparable to similar values obtained for other dielectric moisture-meters used for moisture determination in wheat over a much more limited range.

7. It was found that the range of the Kappa moisture-meter was sufficient for the entire range of moisture contents considered. The divisions on the meter scale were also found to be adequately spaced, so that all readings could be made with sufficient accuracy. 
8. It was observed that there was a very close relationship between the weight of a given volume of moderately compacted coffee parchment and its moisture content. This relationship could perhaps form the basis of a cheap, simple way for roughly evaluating the moisture content of parchment coffee which would be sufficiently accurate for farm use.

9. It was considered that the most convenient method of determining the moisture content from the Kappa meter-reading, the sample weight, and the ambient temperature, is by means of a four-variable addition-type alignment chart or nomogram.

10. Though the linear regression equations established for Kappa moisture-meter, Serial No. 7755, are unlikely to be applicable to other moisturemeters of the same type, additional meters required can be calibrated from this original meter instead of by more tedious primary methods.

\section{RESUMEN}

1. Es necesario que todos los que tengan que ver con la producción, industrialización y manejo de un producto, tal como café verde y en pergamino, cuenten con un método rápido y sencillo para determinar su contenido de humedad.

2. Un repaso de la literatura indica que mucho se ha hecho en cuanto a la determinación de humedad de semillas comerciales de las regiones templadas, pero aparece poca información sobre este aspecto concerniente al café.

3. Como paso inicial en el comienzo de un programa de investigación de métodos para industrializar el café, fué necesario establecer un método rápido, sencillo y exacto para determinar la humedad. Otras investigaciones han indicado que el medidor Kappa para humedad, manufacturado por la firma Kappa Moisture Meter Ltd. U. K., era lo más apropiado para este propósito.

4. Se decidió usar un método de destilación como base para establecer la relación entre el contenido de humedad del material y la lectura obtenida por el instrumento. Se encontró que no era tan sólo necesario determinar la lectura del medidor, si que también el peso de la muestra y la temperatura ambiental, si se deseaba obtener resultados confiables.

5. El medidor Kappa se calibró tanto para café en pergamino como para café pilado, cubriendo el más amplio alcance de variàción en contenido de humedad que pudiera encontrarse.

6. Se evaluaron estadísticamente todos los resultados. Se encontró que si se consideraban el peso de la muestra y la temperatura ambiental, la desviación standard de la regresión o el error standard del estimado para café pergamino y verde eran muy comparables a valores similares obtenidos de otros medidores dieléctricos de humedad usados para la determinación 
de humedad en trigo, dentro de un alcance de variación mucho más limitado.

7. Se encontró que el alcance del medidor Kappa era suficiente para el alcance completo de los contenidos de humedad considerados. Las divisiones de la escala del medidor se encontraron que estaban espaciadas adecuadamente y de tal manera que todas las lecturas podían hacerse con suficiente exactitud.

8. Se observó que hubo una relación muy estrecha entre el peso de un volumen dado de café en pergamino, moderadamente compacto, y su contenido de humedad. Esta relación quizás podría formar la base de una manera barata y sencilla para evaluar aproximadamente el contenido de humedad del café en pergamino con suficiente exactitud para uso en la finca.

9. Se considera que el método más conveniente de determinar el contenido de humedad de la lectura del medidor Kappa, del peso de la muestra y de la temperatura ambiental es mediante el uso de un tipo de carta gráfica de alineación o nomograma con cuatro variables de adición.

10. Aunque las ecuaciones de regresión linear establecidas por el medidor de humedad Kappa, serie 7755, no son aplicables a otros medidores de humedad del mismo tipo, si se requieren medidores adicionales, éstos pueden calibrarse según el medidor original, en vez de hacerlo mediante métodos primarios que son más tediosos

\section{LITERATURE CITED}

1. Anderson, J. A., and Alcock, A. W., Storage of Cereal Grains and Their Products, Amer. Assn. of Chem., Minnesota, U.S., 1954.

2. Barton, Lela V., and Goenaga, A., An electrical moisture meter for the determination of moisture in coffee beans, Contributions from Boyce Thompson Institute, 16 461-8 1952.

3. Bidwell, G. L., and Sterling, W. F., Preliminary notes on the direct determination of moisture, Ind. Eng. Chem. 17 147-9 1925.

4. Cook, W. H., Hopkins, J. W., and Geddes, W. F., Rapid determination of moisture in grains, Can. Research, 2 410-47 1934.

5. Davis, D. S., Nomography and Empirical Equations, 145, Reinhold Publishing Corporation, New York, N. Y. 1955.

6. Davis, R. J., and Hall, C. W., Graphical presentation of mathematical equations, Agr. Eng. J. 35 385-8 1954.

7. Dean, E. W., and Stark, D. S., A convenient method for the determination of water in petroleum and other organic emulsions, Ind. Eng. Chem. 124861920.

8. Determination of Moisture Content, The Kappa Method and Applications. Kappa Moisture Meter Ltd., Rickmansworth, Herts., England.

9. Goto, Baron Y., and Fukunaga, Edward T., Coffee Harvesting and Processing for Top Quality Coffee, Ext. Circ. 358, University of Hawaii, 1956.

10. Haarer, A. E., Modern Coffee Production, 246-56, Leonard Hill (Books) Ltd., London, England, 1956.

11. Hall, Carl W., Drying Farm Crops, 73, Agricultural Consulting Associates, Inc., Reynoldshurg, Ohio, U.S. 1957. 
12. Hlynka, I., Martens, V., and Anderson, J. A. A., A Comparative study of ten electrical meters for determining moisture content in wheat, Can. J. Res., 27F 382-97 1949.

13. Ives, Norton C., Coffee-Drying Studies, Development of a Counter-Flow Continues Dryer for Washed Coffee, Inter-American Institute of Agricultural Sciences, Field Service Unit, Turrialba, Costa Rica, 1953.

14. Llewelyn, D. A. B., Coffee Drying, Report to the Coffee Board of Kenya on Investigations 1955-56, Nairobi, Kenya, 1956.

15. Operation Instructions for the Kappa Moisture Motor, AB/55, 7 Kappa Moisture Meters Ltd., Rickmansworth, Herts., England.

16. Schwartzman, G., Report on moisture in coffee, Assn. Office Agr. Chem. J., 30 648-52 1954.

17. Snedecor, G. W., Statistical Methods, p. 111, The Iowa State College Press, Ames, Iowa, U.S.A., 1946.

18. Storing Coffee Seed, Trop. Agr. (Trinidad) 18251941.

19. Zeleny, Lawrence, Methods of Grain Moisture Determination, Agr. Eng. J., 35 352-6 1954. 